\title{
TREATMENT OF BENZENE VAPORS FROM CONTAMINATED AIR STREAM IN A LABORATORY-SCALE COMPOST BIOFILTER
}

\author{
Eldon R. Rene ${ }^{1}$, D. V. S. Murthy ${ }^{2}$, T. Swaminathan ${ }^{3}$ \\ ${ }^{1}$ Chemical Engineering Laboratory, Faculty of Sciences, University of La Coruña, \\ Alejandro de la Sota, 1, E-15071 La Coruña, Spain \\ ${ }^{2,3}$ Department of Chemical Engineering, Indian Institute of Technology \\ Madras, Chennai - 600036, Tamilnadu, India. \\ eldonrene@yahoo.com
}

\begin{abstract}
Biofiltration of process waste-gas streams using microorganisms attached to porous support matrix, at low concentrations and high gas flow rates, has gained importance as a versatile treatment technology ever since the Clean Air Act Amendments (1990), by the US - EPA came into existence. In this study, we evaluated the potential of a laboratory-scale biofilter, inoculated with mixed culture, to remove gas-phase benzene from a synthetic waste gas stream. Experiments were conducted in three different phases, after the acclimatization step, corresponding to empty bed residence times (EBRT) varying between $0.81-2.45 \mathrm{~min}$ and benzene concentrations up to $1.7 \mathrm{~g} / \mathrm{m}^{3}$. At high concentrations, significant reduction in removal efficiency was observed, which may be due to insufficient biomass in the filter bed to utilize the substrate, or due to substrate inhibition at high concentrations. Removal efficiencies higher than $90 \%$ were achieved for inlet benzene loading rates lesser than $40 \mathrm{~g} / \mathrm{m}^{3} . \mathrm{hr}$.
\end{abstract}

Key words: compost biofilter; benzene; performance; removal efficiency; elimination capacity

\section{ТРЕТМАН НА БЕНЗЕНСКИ ПАРЕИ ОД ЗАГАДЕНА ВОЗДУШІНА СТРУЈА СО ЛАБАРОТОРИСКИ КОМПОЗИТЕН БИОФИЛТЕР}

\begin{abstract}
Процесот на биофилтрација на отпадна гасни струи со користење на микроорганизми прицврстени на порозна матрица, при ниски концентрации и големи протоци на гасот, станува значаен како прилагодлива технологија одкако беше предложен Clean Air Act Amendments (1990) од ЕПА, САД. Во оваа студија се испитува потенцијалот на лабораториски бифилтер, за да се извлече бензен во гасна фаза од синтетичка отпадна гасна струја. Експериментите беа изведувани во три различни фази, по чекорот на аклиматизација, која што одговара на време на престој при празен слој (EBRT) кое што варира од 0,81 до 2,45 мин и концентрации на бензенот до $1,7 \mathrm{~g} / \mathrm{m}^{3}$. При високи концентрации, беше забележано значајно смалување на ефикасноста на извлекувањето, кое може да биде поради недоволната биомаса во филтерот за да го искористи супстратот или поради инхибиција при високи концентрации. Беше постигната ефикасност на извлекување повисока од $90 \%$ за почетни брзини на бензенот помали од $40 \mathrm{~g} / \mathrm{m}^{3} \mathrm{~h}$.
\end{abstract}

Клучни зборови: биофилтер; бензен; перформаси; ефикасност на извлекување; капацитет на елиминација

\section{INTRODUCTION}

Benzene is an important chemical feedstock, which is used as a raw material for the synthesis of fine chemicals and many dye components. Due to improper practices and treatment, a substantial amount of vapors containing benzene are being re- leased to the ambient atmosphere from the process industries. Benzene is reported to have significant effect on human health and the natural environment [1]. This has led to increased attention from the regulatory authorities and continuous development of the existing control technologies. Biodegradation is a promising alternative for the mineralization of 
volatile organic compounds (VOCs). The most widely used biological processes for waste gas treatment are bio-scrubbing, trickling biofilters, and biofilters. The simplicity in operation makes the biofilters a practical and viable treatment option. Biofilters have also proven to be effective in treating large volumes of VOCs at relatively low concentrations [2]. A complex phenomenological step consisting of adsorption, absorption, diffusion and biodegradation takes place in a biofilter where the pollutant is converted to non-toxic end products [3]. Furthermore, the removal and oxidation rates of these hazardous contaminants depend principally on the biodegradability, reactivity and largely on the solubility of the pollutant in the liquid layer of the biofilm. Biofiltration studies have been performed with a wide variety of pollutants having different degradation rates. Removal of ethanol vapors was studied in a compost biofilter that gave a maximum EC of $195 \mathrm{~g} / \mathrm{m}^{3} . \mathrm{hr}$, and results from transient behavior studies have demonstrated a stable biomass activity [4]. Lab scale studies for the removal of toluene vapors in a compost biofilter has shown a maximum elimination capacity (EC) of $128.1 \mathrm{~g} / \mathrm{m}^{3} . \mathrm{hr}$ and when tested with an actual industrial gas mixture containing toluene and benzene showed high removal efficiencies [5]. The removal characteristics for mixtures of $\mathrm{NH}_{3}$ and $\mathrm{H}_{2} \mathrm{~S}$ in a biofilter packed with a novel biomedia encapsulated with an organic polymer showed stable removal efficiencies greater than $99 \%$ for 60 days [6]. These experimental studies have proven that biofiltration is an efficient waste gas treatment process and a reliable technology for the control of VOCs. This paper presents the performance of a compost-based mixed culture biofilter treating benzene vapors at high concentrations.

\section{MATERIALS AND METHODS}

\subsection{Microbial seed}

A mixed microbial culture obtained from a municipal sewage treatment plant was acclimatized with benzene as the carbon source in a well defined mineral salt medium [5]. This culture was used to inoculate the biofilter.

\subsection{Biofilter}

The biofilter was constructed from acrylic tube ( $5 \mathrm{~cm}$ diameter and $70 \mathrm{~cm}$ height). The packing in the biofilter consisted of a mixture of sieved compost (3-6 mm) and ceramic beads (4-6 mm). A perforated plate at the bottom provided the support for the packing while the addition of ceramic beads provided the structural strength for the packed bed. Gas sampling ports sealed with rubber septa were provided at equal intervals along the biofilter height.

\subsection{Experimental}

A schematic of the experimental setup is given in Figure 1. Liquid benzene placed in a trough, was vaporized and humidified at constant air flow rate, controlled through valves and was passed through the bed in an up - flow mode. The compost-based filter bed was inoculated with benzene acclimatized mixed culture, that was initially grown under batch conditions in $250 \mathrm{ml}$ Erlenmeyer flasks, at $30{ }^{\circ} \mathrm{C}$ and with initial benzene concentrations of $150 \mathrm{mg} / \mathrm{l}$. The bed moisture content was maintained periodically by adding fresh mineral salt medium from the top of the bioreactor. The leachate generated was removed with the help of a port at the bottom. Experiments were carried out by varying the flow rates of the benzene vapors and humidified air, independently to get different initial concentrations and empty-bed residence times in the biofilter. Gas samples were collected from different ports and analyzed for residual benzene concentration.

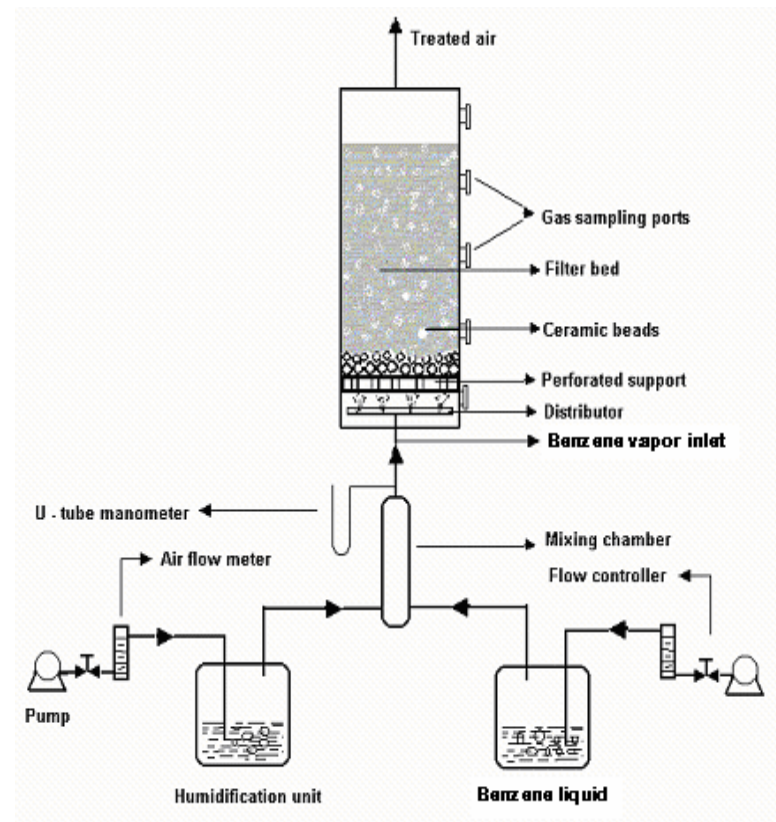

Fig. 1. Schematic of the experimental biofilter setup 


\subsection{Analytical methods}

The benzene concentration in the gas samples were measured by gas chromatography (Model 5765, Nucon gas chromatograph, Nucon Eng. India) fitted with a stainless steel column and a flame ionization detector. Nitrogen was employed as the carrier gas at a flow rate of $20 \mathrm{ml} / \mathrm{min}$. The temperatures at the GC injection, oven, and detection ports were 150,120 , and $250^{\circ} \mathrm{C}$ respectively.

\section{RESULTS AND DISCUSSION}

The performance of the biofilter was evaluated in terms of two parameters, the removal efficiency (RE, \%) and the elimination capacity of the filter bed (EC, $\mathrm{g} / \mathrm{m}^{3} . \mathrm{hr}$ ), which can be represented by,

$$
\begin{gathered}
R E=\frac{C_{g i}-C_{g o}}{C_{g i}} \times 100 \\
E C=\frac{Q\left(C_{g i}-C_{g o}\right)}{V}
\end{gathered}
$$

Where, $\mathrm{C}_{\mathrm{gi}}$ and $\mathrm{C}_{\mathrm{go}}$ are the inlet and outlet benzene concentration in the biofilter, $\mathrm{g} / \mathrm{m}^{3}, \mathrm{~V}$ is the volume of the filter bed, $\mathrm{m}^{3}$ and $\mathrm{Q}$ is the gas flow rate, $\mathrm{m}^{3} / \mathrm{hr}$.

The biofilter was initially acclimatized by operating the biofilter at low concentrations $(0.04-$ $0.07 \mathrm{~g} / \mathrm{m}^{3}$ ) and low gas flow rates of $0.06 \mathrm{~m}^{3} / \mathrm{hr}$ for 45 days to obtain sufficient biomass concentration in the filter bed. The degree of acclimatization primarily depends on the adaptive capability of the microorganisms present in the compost or peat, substrate concentrations, nutrient concentration, and its availability and other necessary environmental conditions. However, the efficient functioning of any biofilter unit strongly depends on the inlet pollutant load [7]. The combined effect of benzene inlet concentration and gas flow rate was investigated in three phases (I, II and III) as described in Table 1 and the results are shown in Figure 2. It can be observed that the biofilter operated at high efficiencies (60-90\%) up to an initial concentration of about $1.6 \mathrm{~g} / \mathrm{m}^{3}$. The outlet concentration remained fairly uniform even when the inlet concentrations were fluctuating. At higher concentrations, the removal efficiency decreased rapidly to $40 \%$. Similarly, the removal efficiency decreased with increase in flow rate. Figure 3 shows the effect of inlet concentration on the removal efficiency throughout the experimental period. Higher concentrations show a significant reduction in removal efficiency, which may be due to insufficient biomass in the filter bed to utilize the substrate, or due to substrate inhibition at high concentrations. Moreover, the removal profiles of benzene vapor at higher concentrations suggest that the biomass concentration in the filter bed may be the limiting factor. The elimination capacity, which reflects the capacity of the biofilter to remove the pollutants, is plotted as a function of the inlet benzene load in Figure 4. A near linear relation between the two variables was observed up to an inlet load of $40 \mathrm{~g} / \mathrm{m}^{3} . \mathrm{hr}$, which corresponded to phase I and phase II operations. However for higher initial concentration and higher flow rate used in phase III, the elimination capacity of the filter bed increased initially and soon became constant at higher inlet loads. At inlet loads beyond $60 \mathrm{~g} / \mathrm{m}^{3}$.hr and up to $130 \mathrm{~g} / \mathrm{m}^{3}$.hr, the EC remained nearly constant between 30 $65 \mathrm{~g} / \mathrm{m}^{3} . \mathrm{hr}$. The biofilter was able to achieve a maximum removal capacity of $64.8 \mathrm{~g} / \mathrm{m}^{3} . \mathrm{hr}$ at an inlet load of $124.8 \mathrm{~g} / \mathrm{m}^{3}$.h. This trend also substantiates the fact that biomass concentrations may be the limiting factor in benzene removal at higher concentrations. The results from this study were comparable to some of the studies reported in literature using compost biofilters. The dynamics of benzene removal was revealed by plotting the normalized benzene concentration profiles as a function of the biofilter height (Figure 5). The results indicate that the removal is more efficient in the lower part of the biofilter than in the upper part of the filter. Nearly $40 \%$ of benzene was removed in the first $20 \mathrm{~cm}$ of the bed height, while the rest of the $30 \mathrm{~cm}$ removed only an additional $20-$ $25 \%$. This may be due to a higher concentration of microbial population and higher moisture content [8] in the lower section of the filter bed. Zilli et al [9] had shown that higher biomass concentration near the inlet of the biofilter was due to the higher benzene loading rates in the inlet zone that stimulated the pollutant bio-oxidation and cell development. The results from their study showed a maximum removal capacity of $20.1 \mathrm{~g} / \mathrm{m}^{3} . \mathrm{hr}$ at benzene - loading rate of $24.8 \mathrm{~g} / \mathrm{m}^{3} . \mathrm{hr}$. 


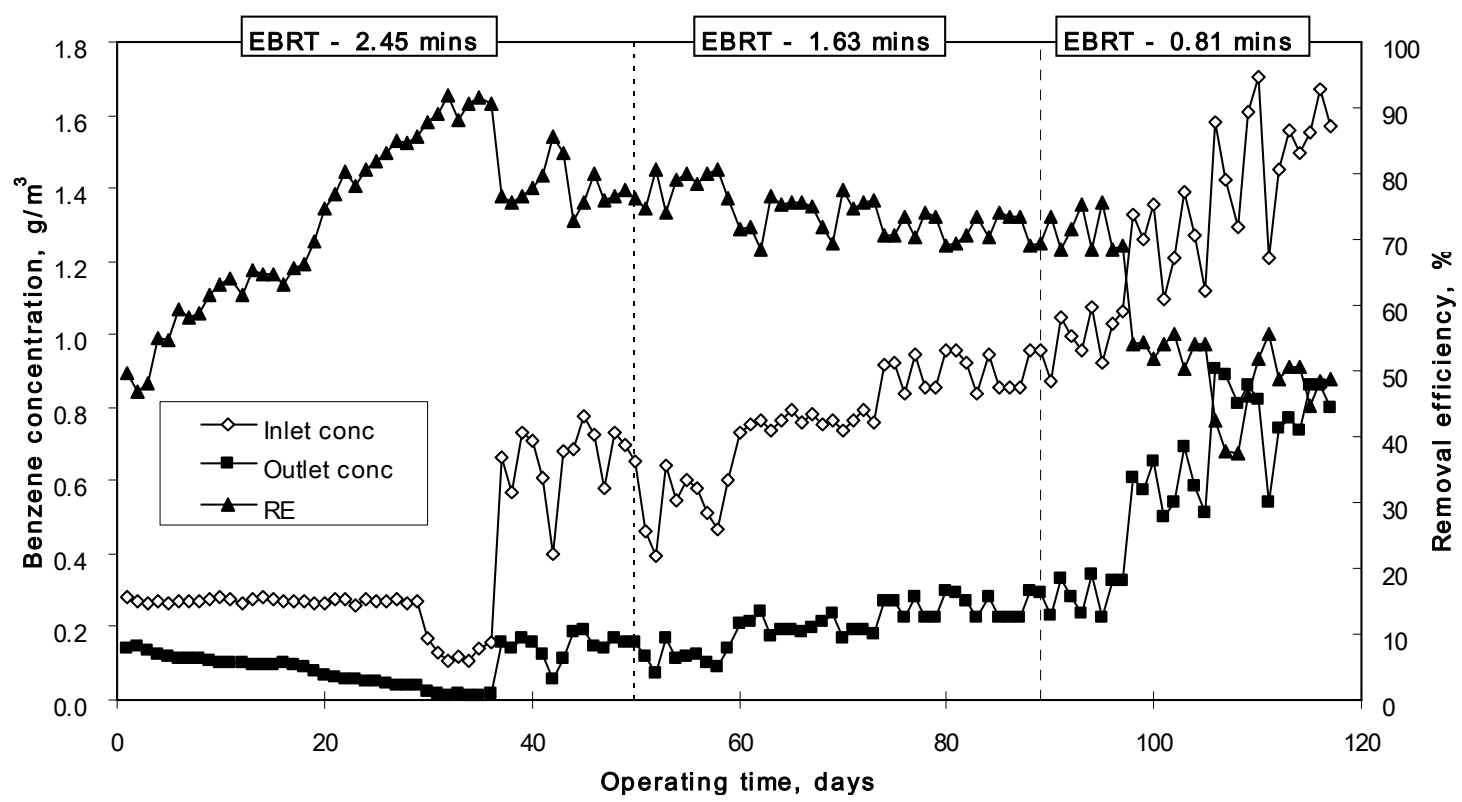

Fig. 2. Variation in removal efficiency with change in gas flow rate and inlet benzene concentrations.

Table 1

\section{Experimental scheme for continuous benzene degradation experiments}

Phases of biofilter Empty Bed Average inlet Operating operation Residence Time concentrations time

\begin{tabular}{lccc} 
& $\min$ & $\mathrm{g} / \mathrm{m}^{3}$ & days \\
\hline Acclimatization & 1 & $0.04-0.07$ & 45 \\
Phase I & 2.45 & $0.2-0.8$ & 50 \\
Phase II & 1.63 & $0.4-1.0$ & 39 \\
Phase III & 0.81 & $0.8-1.7$ & 28 \\
\hline
\end{tabular}

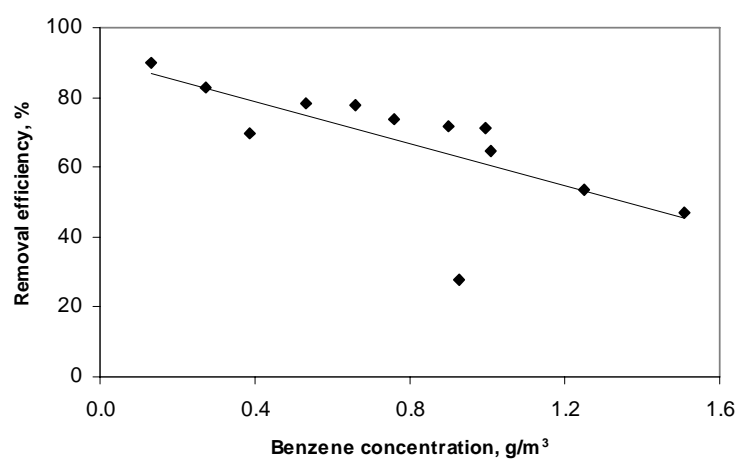

Fig. 3. Influence of the inlet benzene concentration on the removal efficiency of the biofilter (points represented here are the average for each experimental run).

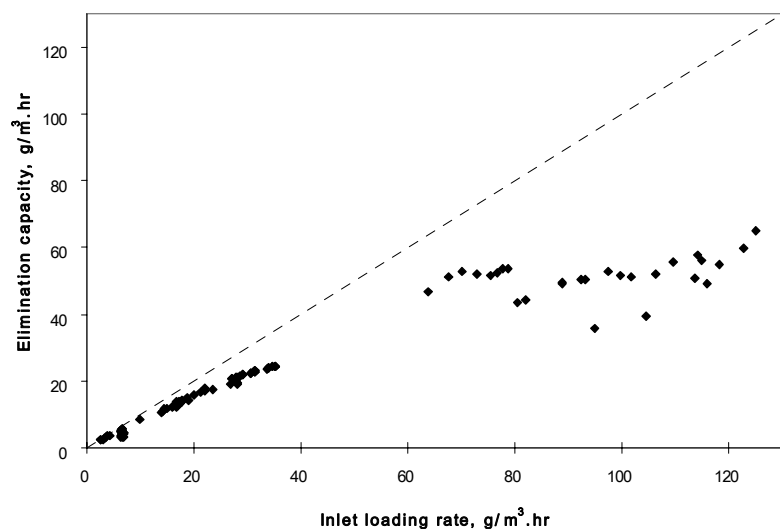

Fig. 4. Influence of inlet benzene load on the elimination capacity of the biofilter.

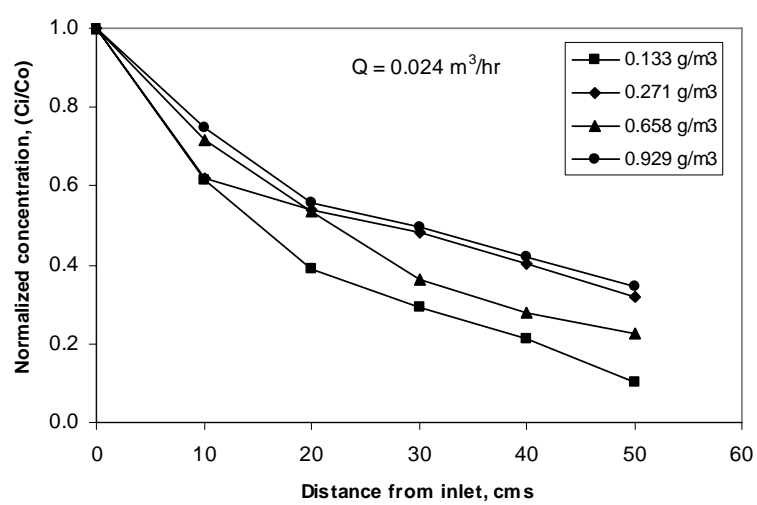

Fig. 5. Normalized benzene concentration profiles as a function of the biofilter height 


\section{CONCLUSION}

The performance of the biofilter was assessed by studying the effects of flow rate and inlet benzene concentration on the removal efficiency and elimination capacities of the filter bed. The biofilter attained a maximum elimination capacity of $64.8 \mathrm{~g} / \mathrm{m}^{3} . h r$ at an inlet load of $124.8 \mathrm{~g} / \mathrm{m}^{3} . \mathrm{hr}$. The removal efficiencies were greater than $80 \%$ when the gas flow rate was $0.024 \mathrm{~m}^{3} / \mathrm{hr}$ and the inlet concentration was less than $0.5 \mathrm{~g} / \mathrm{m}^{3}$. The results presented here suggest that the compost biofilter system, subject to further optimization, could offer enormous potential for the biological removal of vapor phase benzene from industrial emissions.

Acknowledgements. The authors would like to gratefully thank the Swedish International Development Agency (SIDA) for its partial financial support towards this work.

\section{REFERENCES}

[1] WHO, Occupational Diseases, Macmillan Publishers, Singapore, 1986.
[2] S. P. P. Ottengraf, Exhaust Gas Purification, In: Biotechnology, H. J. Rehm and G. Reed. (eds.), 425-452, VCH Verlagsgesellschraft, Weinham, Germany (1986).

[3] J. S. Devinny, M. A. Deshusses, T. S. Webster, Biofiltration for Air Pollution Control, Lewis Publishers, Boca Raton (1999).

[4] D. Arulneyan, T. Swaminathan, Biodegradation of ethanol vapors in a biofilter, Bioproc. Eng., 22, 63- 67 (2000).

[5] E. R. Rene, D. V. S. Murthy, T. Swaminathan, Performance evaluation of a compost biofilter treating toluene vapors, Proc. Biochem., 40, 2771-2779 (2005).

[6] J-H. Kim, S-H. Park, C-H. Park, H-S. Park, Removal characteristics of $\mathrm{NH}_{3}$ and $\mathrm{H}_{2} \mathrm{~S}$ in biofilter packed with biomedia encapsulated by organic polymer, J. Korea Soc. Waste. Mgmt., 21, 288-295 (2004).

[7] H. Jorio, L. Bibeau, G. Viel, M. Heitz, M, Effects of gas flow rate and inlet concentration on xylene vapors biofiltration performance, Chem. Eng. Sci., 76, 209-221 (2000).

[8] E. R. Rene, M. C. Veiga, C. Kennes, Performance of a biofilter for the removal of high concentrations of styrene under steady and non-steady state conditions, J. Hazard. Mat. (2009) In Press.

[9] M. Zilli, C. Guarino, D. Daffonchio, S. Borin, A. Converti, Laboratory-scale experiments with a powdered compost biofilter treating benzene-polluted air. Proc. Biochem., 40, 2035 - 2043 (2005). 